\title{
Ocean drilling project fishes for members
}

[SYDNEY] The JOIDES Resolution, research vessel of the international Ocean Drilling Program (ODP), began its first drilling leg in New Zealand waters this month. But the project - to investigate the circulation of cold Antarctic bottom water - is in urgent need of new members.

Since June, when the Canadian Kathryn Moran took over as ODP director, the programme has relaxed conditions which previously allowed membership only to nations, or consortia of nations, that would pay an annual subscription of US $\$ 3$ million.

Speaking in Sydney during the ship's routine change of scientific teams, Moran said that the programme is working hard to cover its costs at the current funding level of US $\$ 45$ million. The US National Science Foundation, which pays about half of this, "may pick up the slack for one year but cannot sustain extra funding beyond that," she says.

In 1996, France threatened to withdraw from the programme, questioning its scientific value and perceived US orientation (see Nature 379, 193; 1996). Last June, France reduced its contribution by a third and to accommodate this the ODP created an 'associate member' category - which also permitted the admission of China on payment of one-sixth of a subscription.

The United States, Britain, Germany and Japan have renewed full membership and two consortia bring in other members - the European group with 12 partners and the Pacific Rim group which now has four.

When Canada halved its two-thirds share

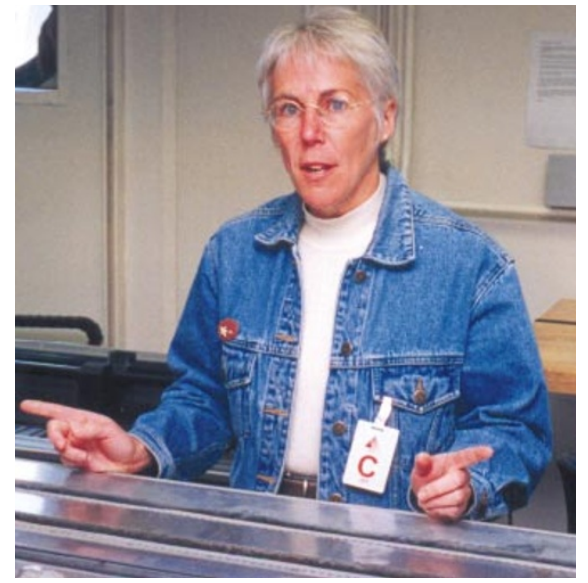

Kathryn Moran: balancing the books to keep JOIDES Resolution afloat after 2003.

in the Pacific Rim group in 1995, the partnership with Australia (one-third) was in difficulty until South Korea joined with onetwelfth and Taiwan contributed one-sixth. Jock Keene, the director of the Australian ODP office, is concerned that the consortium will be unstable as long as it is one-twelfth short of a full subscription. It is being allowed full membership rights as it tries to secure another partner, possibly New Zealand.

Funding cutbacks recently required the Australian Geological Survey Organisation to stop leasing Rig Seismic, the only vessel able to conduct marine geology on Australia's continental shelf. Keene says that Australia will struggle to attract more ODP research in Australian waters, because it won't be able to conduct the surveys needed to prepare for voyages of the JOIDES Resolution.

A recent expedition to the Woodlark Basin, east of Papua New Guinea, yielded cores containing bacteria living 842 metres below the ocean floor, almost 100 metres deeper than the previous record. But the voyage highlighted a major deficiency in the ship's capabilities: at an active fault zone on Australia's continental margin, it had to withdraw on detecting signs of hydrocarbons. The vessel is not equipped with pressure-limiting 'risers' to contain the risk of blowout.

Researchers have called for drilling with risers into the hard rock of the deeper crust. Japan is expected to decide this year whether to build a research ship of its own that would be twice the size of JOIDES Resolution and able to satisfy this need (see Nature 388, 409; 1997). Some see this plan as endangering the ODP after 2003, when the programme and the ship lease are due to be reviewed, but Moran says that a more diverse research programme could be built around JOIDES Resolution and the Japanese ship.

Her strategy for now is to seek more fractional members such as India, South Africa, Brazil, Eire and perhaps the US Department of Energy (via its interest in exploring for gas hydrates), and to enter partnerships with consortia of commercial oil companies.

But some ODP participants fear that relaxed membership conditions will encourage other nations to follow France's lead, and try to reduce their subscriptions while retaining a place in the programme. PeterPockley

\section{Spending spree propels Finland towards top of research league}

[HELSINKI] Finland is on target to meet its goal of a research funding level of 2.9 per cent of gross national product by next year, as both public and private sources of funds increase at a rate envied by its European neighbours.

The increase in funding places this nation of five million people among the world's biggest spenders on research. The new money is accompanied by policy changes which have led to a greater concentration of effort in areas of strategic importance, such as information technology and molecular genetics, and greater coordination of academic and industrial research.

The change in fortune has allowed Finland to implement within 18 months nearly all the recommendations made by the European Molecular Biology Organization which coordinated an external review of Finland's performance in molecular biology (see Nature 385, 666; 1997). These include the establishment of a new FM30 million (US\$5.5 million) institute for genomics and bioinformatics research in Helsinki which coordinates input from three other new university genomics centres, and a similarly organized institute for structural biology.

To support these initiatives the Finnish Academy of Sciences, which distributes much of Finland's basic research funds, has set up new programmes in microbiology, cell biology and transgenics, as well as a five-year programme for genomics, and a smaller programme in microbial ecology. It has made genetics one of the priorities of its new $\mathrm{PhD}$ programmes. "The changes were made easy for us, because the new money meant we were spared the difficulties of reallocating money from other areas," says Reijo Vihko, president of the academy.

The ministry for research has recently agreed to maintain direct funding for biotechnology which was due to stop this year.

Finnish scientists seem to be using the new money efficiently. The number of Finnish papers per capita published in refereed journals has doubled over the past decade, overtaking the productivity of

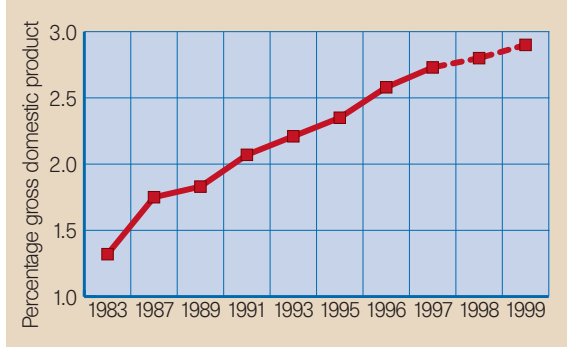

Steady progress: Finnish R\&D spend since 1983.

Germany, Norway and the United States. Finland's rate of return from European Union research programmes is the third highest among the 15 states in the union.

In the past few years the academy has managed to lower the average age of gaining a $\mathrm{PhD}$ from 38 to 34, and the total number of graduate school positions is set to rise. The experimental centres of excellence programme, which some Finns believe concentrates research funds too heavily for a small country, will be expanded. Alison Abbott 